\title{
PERAN LEMBAGA WILAYATUL HISBAH DALAM SISTEM PEREKONOMIAN ISLAM
}

\author{
Abdul Hamid \\ hamidzckl@gmail.com \\ IAIN Langsa \\ Uun Dwi Al Muddatstsir \\ Uundwi@gmail.com \\ Program Doktor Ekonomi Syariah \\ Pascasarjana Universitas Islam Negeri Sumatera Utara
}

\begin{abstract}
To control / supervise the implementation of Islamic Shari'at in the field the Regional Government establishes a Wilayatul Hisbah (WH) body whose work procedures and authorities are regulated in the Decree of the Governor of Nanggroe Aceh Darussalam Number 01 of 2004. In applying certain aspects of sharia law. Therefore, improving the quality of human resources through the Islamic structural values approach is considered by many to be the right step, because it can control deviations and is also in accordance with the cultural values of the Acehnese people, which have historically been known with three features, namely, education , religion and customs.
\end{abstract}

Key words: Wilayatul Hisbah and Islamic Economic System

\begin{abstract}
Abstrak
Untuk mengontrol/mengawasi Pelaksanaan Syari'at Islam di lapangan Pemerintahan Daerah membentuk badan Wilayatul Hisbah (WH) yang tata kerja dan kewenangannya di atur dalam keputusan Gubernur Nanggroe Aceh Darussalam Nomor 01 tahun 2004. Di dalam menerapkan beberapa aspek-aspek tertentu dari hukum syariah. Oleh sebab itu peningkatan kualitas sumber daya manusia melalui pendekatan nilai-nilai struktural keIslaman dinilai banyak pihak merupakan langkah yang tepat, karena dapat mengontrol penyimpangan dan sesuai pula dengan nilai-nilai kebudayaan masyarakat Aceh dahulu, yang secara historis telah dikenal dengan tiga keistimewaan yaitu, pendidikan, agama dan adat istiadat.
\end{abstract}

Kata kunci: Wilayatul Hisbah dan Sistem Perekonomian Islam 


\section{Pendahuluan}

Penyebaran Islam ke Indonesia secara intentif dimulai pada abad VI Masehi. Aceh merupakan wilayah pertama kali yang menerima Islam. Masyarakat Aceh amat tunduk kepada ajaran Islam dan mereka taat serta memperhatikan fatwa ulama, karena ulamalah yang menjadi pewaris Nabi Saw. Penghayatan terhadap ajaran Islam dalam masa yang panjang itu telah melahirkan budaya Aceh yang tercermin dalam kehidupan adat berdasarkan dari renungan para ulama kemudian di praktekkan, dikembangkan dan dilestarikan, lalu disimpulkan menjadi "Adat bak Poteomeureuhom, hukom bak Syiah Kuala, Qanun bak Putro Phang, Reusam bak laksamana" yang artinya "Hukum adat di tangan pemerintah dan hukum syari'at ada di tangan Ulama". Kata-kata ini merupakan pencerminan dari perwujudan Syari'at Islam dalam praktek hidup sehari-hari bagi masyarakat Aceh masa itu.

Mungkin agak terasa asing ketika pertama kali menyebut istilah kata hisbah bagi sebagian masyarakat di Indonesia. Meskipun di Indonesia mayoritas penduduknya adalah beragama Islam. Salah satu wilayah di Indonesia yang menerapkan lembaga hisbah yaitu di NAD ( Nangro Aceh Darusalam). Hisbah merupakan cara pengawasan terpenting yang dikenal oleh umat Islam pada masa permulaan Islam yang berfungsi untuk melakukan pengawasan terhadap seluruh lini kehidupan umat Islam, meluruskan etika dan mencegah penyimpangan. Lembaga ini merupakan salah satu bentuk upaya dari pemerintah untuk menciptakan kemaslahatan bersama, menumbuhkan kejujuran dan keadilan dalam menegakkan hukum Islam di setiap aspek kehidupan masyarakat.

Tujuan umumnya adalah untuk menjaga lingkungan masyarakat dari kerusakan, dan memastikan kesejahteraan masyarakat baik dalam hal keagamaan ataupun tingkah laku sehari-hari sesuai dengan hukum Allah. Jadi tujuan hisbah tidak hanya untuk memungkinkan pasar dapat beroperasi dengan bebas sehingga harga, upah, dan laba dapat ditentukan oleh kekuasaan permintaan dan penawaran, melainkan juga untuk menjamin bahwa semua agen ekonomi dapat memenuhi tugasnya antara satu dengan yang lain dan mematuhi peraturan hukum Islam yag berlaku. Setiap tindakan atau keputusan yang di ambil harus berhati-hati dalam memutuskannya. Tidak ada unsur pemaksaan, penipuan, pemanfaatan kesempatan dalam kesempitan, atau pengabaiaan terhadap pihak yang melakukan akad, dan tidak ada penimbunan dan perusakan pasokan dengan tujuan menaikkan harga.

Ibnu Taimiyah menuliskan bahwa, "kesejahteraan umat manusia tidak dapat diwujudkan kecuali di dalam suatu tata sosial dimana setiap orang tergantung satu sama lain. Masyarakat memerlukan seseorang untuk mengatur mereka. Perintah Allah SWT untuk menegakkan amar makruf dan nahi mungkar tidak akan dapat direalisasikan kecuali dengan kekuatan dan kekuasaan." Hisbah juga berkaitan dengan hubungan antar pemerintah sebagai petugas hisbah yang nantinya akan mengatur setiap hal-hal yang berkaitan dengan sistem kehidupan masyarakat banyak. 


\section{Pengertian dan Tujuan Hisbah}

Secara harfiyah (etimologi) hisbah berarti melakukan suatu tugas dengan penuh perhitungan (Ahmad 2001). Sedangkan Dr. Jaribah mendefinisikan hisbah secara etimologi berkisar pada memerintahkan kebaikan dan mencegah kemungkaran (amar ma'ruf nahi mungkar). Makna terminology adalah memerintahkan kebaikan apabila ada yang meninggalkannya dan melarang kemungkaran apabila ada yang mengerjakannya (al-Haritsi 2006: 587).

Konsep hisbah diatas mengulas agar bisa mencakup semua anggota masyarakat yang mampu memerintahkan kebaikan dan mencegah kemungkaran. Sebagaimana ruang lingkup hisbah mencakup sisi kehidupan termasuk bidang ekonomi.

Hisbah dapat diartikan juga sebagai lembaga yang fungsi pokoknya adalah menghimbau agar masyarakat melakukan kebaikan dan menjauhi kemungkaran. Namun demikian wilayah fungsi kontrol ini tidak sebatas bidang agama dan moral. Tetapi menurut Muhammad al-Mubarak melebar ke wilayah ekonomi dan secara umum bertalian dengan kehidupan kolektif atau publik untuk mencapai keadilan dan kebenaran menurut prinsip Islam dan dikembangkan menjadi kebiasaan umum pada satu waktu dan tempat.

Landasan Hukumnya adalah al-Qur'an surat Ali Imran ayat 104 yang artinya; "Dan hendaklah ada di antara kamu segolongan umat yang menyeru kepada kebajikan, menyuruh kepada yang makruf, dan mencegah dari yang mungkar, mereka itulah orang-orang yang beruntung”. Al-Qur'an Surat An-Nahl: 90, yang artinya, "sesungguhnya Allah menyuruh (kamu) berlaku adil dan berbuat kebajikan, memberi kepada kaum kerabat, dan Allah melarang dari perbuatan keji, kemungkaran dan permusuhan. Dia memberi pengajaran kepadamu agar kamu dapat mengambil pelajaran." Dasar hukum berupa hadis yaitu; Nabi Muhammad SAW bersabada: "Barang siapa yang melihat kemungkaran, maka rubahlah dengan tangannya. Jika ia tidak bisa, maka rubahlah dengan mulutnya. Jika ia tidak bisa juga, maka dengan hatinya, dan itu adalah selemah-lemahnya iman." Di Indonesia dalam kaitan dengan masalah pengawasan di bidang ekonomi (bisnis), apabila mengacu pada perundangan yang berlaku, antara lain diatur dalam Undang-Undang Republik Indonesia Nomor 5 Tahun 1999 tentang Larangan Praktik Monopoli dan Persaingan Usaha Tidak Sehat (Muhammad 2004: 176). Selanjutnya juga dalam Undang-Undang Republik Indonesia Nomor 8 Tahun 1999 tentang Perlindungan Konsumen. Fungsi pengawasan yang diatur dalam kedua undang-undang ini menitikberatkan pada masalah pengawasan dalam bidang usaha (bisnis) dengan maksud agar kepentingan masyarakat, terutama konsumen, bisa terlindungi. Dengan demikian dilihat dari fungsi pokok yang dibebankan, secara substansial sama dengan fungsi pengawasan dalam institusi hisbah dalam Islam.

Hisbah dalam kegiatan ekonomi mempunyai beberapa tujuan. Pengawasan pasar merupakan tugas pertama seorang muhtasib (pengawas) pada masa 
permulaan Islam. Untuk itu pembahasan ini dibagi menjadi dua, yaitu; pertama, tujuan hisbah dalam kegiatan ekonomi adalah untuk mewujudkan tujuan-tujuan berikut (al-Haritsi 2006: 591):

a. Memastikan dijalankannya aturan-aturan kegiatan ekonomi. Peran pengawasan dari luar untuk mencegah orang-orang yang lalai untuk menjaga aturan-aturan kegiatan ekonomi. Aturan terpentingnya adalah: Disyariatkannya kegiatan ekonomi, aturan terpenting kegiatan ekonomi dalam Islam adalah bahwa kegiatan ekonomi tersebut disyariatkan. Senantiasa terhindar dari maisir, gharar, dan riba. Menyempurnakan pekerjaan dan melawan penipuan. Penipuan merupakan satu tindakan buruk yang dapat menyebabkan bahaya besar tehadap umat dan juga kegiatan ekonominya. Di mana penipuan mempunyai akibat bagi kesejahteraan konsumen,dan juga pertumbuhan ekonominya. Bentukbentuk penipuan ini dapat berupa: kualitas, kuantitas, harga dan waktu penyerahan barang/jasa (A. Karim 2007: 203). Tidak membahayakan orang lain

b. Mewujudkan keamanan dan ketentraman. Keamanan dan ketrentraman merupakan menciptakan iklim investasi yang sesuai, dan mewujudkan pertumbuhan ekonomi.

c. Mengawasi keadaan rakyat. Menurut Umar bin Khattab tujuan hisbah adalah berjalan pada malam dan siang hari untuk mengetahui keadaan rakyat, mengetahui kebutuhan-kebutuhan mereka, dan menyantuni orang-orang yang membutuhkan (al-Haritsi 2006: 596).

d. Melarang orang membuat aliran air tanpa adanya kebutuhan. Islam memerintahkan agar setiap orang berusaha mewujudkan ketercukupan untuknya dan ketercukupan untuk orang yang berada dalam tanggungannya dan tidak memperbolehkan orang yang mampu menjadi beban orang lain (al-Haritsi 2006: 597).

e. Menjaga kepentingan umum. Kepentingan umum adalah kemaslahatan bagi umat, dimana umat tidak bisa terpisah dari kepentingan tersebut. Maka harus ada pengawasan terhadap kepentingan umum tersebut untuk menjaga dan melindunginya dari orang yang berbuat sia-sia (al-Haritsi 2006: 596).

f. Mengatur transaksi di pasar. Pengawasan pasar dan mengatur persaingan di dalamnya yaitu dengan memerangi transaksi yang merusak persaingan tersebut.

Kedua, tujuan hisbah terhadap pasar. Pasar mempunyai peran yang besar dalam ekonomi. Pasar adalah tempat yang mempunyai aturan yang disisipkan untuk tukar menukar hak milik dan menukar barang antara produsen dan konsumen. Tujuan terpenting dari pengawasan pasar dan aturan transaksi di dalamnya yaitu: 
a. Kebebasan keluar masuk pasar. Kebebasan transaksi dan adanya persaingan yang sempurna di pasar Islam tidak terwujud selama halanganhalangan tidak dihilangkan dari orang-orang yang melakukan transaksi di pasar. Maka mereka masuk pasar dan keluar dengan bebas,juga di berikan kebebasan mengangkut barang dari satu tempat ke tempat lain dan memindahkan unsur produksi diantara bermacam - macam kegiatan ekonomi sesuai fluktuasi persediaan dan permintaan barang.

b. Mengatur promosi dan propaganda. Tujuan pengawasan pasar adalah menunjukkan para pedagang tentang cara-cara promosi dan propaganda yang menyebabkan lakunya dagangan mereka. Dengan syarat dalam masyarakat Islam berdiri atas dasar kejujuran dan amanat dalam semua cara yang diperbolehkan untuk memperluas area pasar di depan barang yang siap dijual.

Ketiga, larangan menimbun barang. Penimbunan barang adalah halangan terbesar dalam pengaturan persaingan dalam pasar Islam. Para pelaku monopoli mempermainkan barang yang dibutuhkan oleh umat dan manfaatkan hartanya untuk membeli barang, kemudian menahannya sambil menunggu naiknya harga barang itu tanpa memikirkan penderitaan umat karenanya perilaku ini dilarang oleh Islam.

Monopoli identik dengan penimbunan. Pembahasan monopoli muncul sebagai akibat dari masalah pemberian harga karena persaingan tidak sempurna. Prinsipnya adalah seseorang tidak boleh menimbun hanya karena ingin memperoleh harga yang lebih tinggi dan menyengsarakan atau member dampak negative bagi orang lain. Dan praktek monopoli ini justru akan membunuh mekanisme kebebasan pasar.

Dengan menahan dan menyembunyikan, sesungguhnya, menyebabkan seseorang menjadi lebih miskin dalam arti yang sebenarnya. Sebab dengan demikian miliknya tidak dapat digunakan orang lain di masa kekurangan. Sebagai upaya akhir sesungguhnya Negara Islam mempunyai wewenang untuk mencabut hak milik perusahaan spekulatif dan anti sosial dalam melakukan penimbunan. Tindakan tegas ini untuk mencegah kenaikan harga yang tidak semestinya.

Keempat, mengatur perantara perdagangan. Kelima, pengawasan harga. Sangat harmonis kehidupan ekonomi yang diatur secara islami, bila diterapkan dengan disiplin. Tidak akan pernah ada praktek-praktek yang tidak sehat dalam bisnis karena sejak Rasulullah SAW telah melarangnya. Beliau tidak menganjurkan campur tangan apapun dalam proses penentuan harga oleh Negara ataupun individual, apalagi bila penentuan harga ditempuh dengan cara merusak perdagangan yang fair antara lain melalui penimbunan barang.

Negara disini adalah membiarkan pasar secara bebas sesuai faktor-faktor alamiah tanpa campur tangan pihaknya yang memaksakan orang untuk menjual dengan harga yang tidak mereka setujui atau untuk membeli dengan harga yang tidak mereka terima. Sehingga sangat sejajar dengan pendapat Ibnu taimiyah 
tentang mekanisme pasarnya bahwa harga di tentukan berdasarkan tingkat demand dan suplly secara alami (A. Karim 2010: 364). Namun tidak sekaligus melepaskan peran lembaga hisbah sebagai bentuk pengawasanya sampai tidak ada pihak yang terdzolimi.

Keenam, pengawasan barang yang diimpor. Pada masa Umar bin Khattab telah menunjuk para pengawas pasar. Diantara tugasnya adalah mengawasi barang yang diimpor dan mengambil Usyur (pajak 10\%) dari barang tersebut dengan tingkatan yang berbeda sesuai pentingnya barang tersebut dan kebutuhan umat Islam kepadanya (al-Haritsi 2006: 618). Tujuan dibalik hisbah tidak hanya memungkinkan pasar dapat beroperasi secara bebas sehingga harga, upah dan laba dapat ditentukan oleh kekuatan permintaan dan penawaran melainkan juga untuk menjamin bahwa semua agen ekonomi dapat memenuhi tugasnya antara satu sama lain dan mematuhi ketentuan syariat (Chapra 2001: 64).

\section{Peran Lembaga Hisbah dalam Perekonomian (Bisnis) Islam}

Dalam sejarah perekonomian Islam, terdapat suatu lembaga yang dinamakan hisbah, yang tugasnya adalah memantau, mengawasi praktik-praktik kegiatan perekonomian yang tidak sesuai dengan kaidah al-Qur'an dan Hadist. Lembaga ini dapat membimbing jalannya kehidupan masyarakat kearah sesuai dengan al-Qur'an dan Hadist. Sehingga masalah kemiskinan dapat terpecahkan. Memang masalah kemiskinan adalah karena tidak dilakukannya kegiatan perekonomian sebagaimana yang diatur dalam al-Qur'an dan Hadist. Hisbah mempunyai peran yang sangat penting dalam Ekonomi (bisnis), yaitu: pertama, standarisasi Mutu yang cukup tinggi. Masyarakat khususnya kaum pedagang harus menyediakan barang terbaiknya karena hisbah juga mengatur tentang mutu barang yang ada di masyarakat. Ketika ada penipuan atau kecurangan mutu barang yang dilakukan oleh produsen dan mendzalimi konsumen, maka petugas hisbah siap bertindak. Kualitas barang harus sesuai dengan harga yang di tetapkan produsen dan yang dijanjikan oleh produsen kepada konsumen. Produsen pun tidak bisa menjiplak karya produsen lain, karena dengan adanya peniruan dalam karya produksi akan menyebabkan kerugian baik bagi produsen yang punya hak cipta atau bagi masyarakat pengguna. Dan jelas, penjiplakan yang mendzolimi dilarang dalam Islam.

Kedua, regulasi perdagangan lebih teratur. Lembaga hisbah mempunyai pengawas yang siap mengawasi setiap kezaliman dalam perdagangan, maka masyarakat akan cenderung hati-hati dalam berdagang. Apalagi ada dasar AlQur'an dan ketakutan yang tinggi pada Allah menjadikan masyarakat lebih jujur dalam berdagang, lebih jujur dalam menyediakan supply barang, tidak ada lagi penimbunan barang yang membuat peningkatan harga di masyarakat. Dengan adanya regulasi ini system perdagangan lebih terkendali.

Ketiga, terhindarnya ekonomi biaya tinggi. Dengan regulasi yang teratur juga akan menyebabkan biaya yang tercipta rendah karena tidak ada uang pungutan liar sana-sini yang biasa di pungut oleh pihak birokrat ataupun orang- 
orang yang ingin mengambil keuntungan diatas penderitaan orang lain. Keempat, harga yang terbentuk di masyarakat

Dengan adanya lembaga Hisbah ini harga yang terbentuk di masyarakat lebih stabil karena senantiasa ada pengawasan.Bila harga terlalu tinggi maka dapat diatur khususnya kebutuhan bahan pokok. Hisbah akan melindungi masyarakat dari harga yang mencekik yang umumnya di lakukan oleh perusahaan yang bermain secara monopoli.

Kelima, kesejahteraan Masyarakat akan lebih merata. Ketika barang yang dibutuhkan masyarakat hadir secara cukup dengan harga yang layak, akan membuat masyarakat jauh dari kemiskinan dan dekat dengan kesejahteraan. Pendapatan dan kepemilikan barang akan cenderung merata atau distribusi merata. Sehingga gap atau kecemburuan sosial dapat di cegah. Keenam, kecerdasan masyarakat dalam ekonomi yang berperan di Hisbah tidak hanya petugas hisbah saja, namun juga masyarakat umum. Karena pengaduan akan kedzoliman bisa saja di lakukan oleh masyarakat umum. Secara tidak langsung, masyarakat di buat untuk lebih punya pemahaman dalam hal ekonomi dan bisnis, agar tidak mudah untuk di dzolimi dan agar bisa membantu anggota masyarakat lain yang sedang terdzolimi.

\section{Kewenangan Lembaga Hisbah dan kewenangan dalam Mengatur Bisnis}

Seiring pemberlakuan undang-undang Republik Indonesia No 44 tahun 1999 tentang penyelenggaraan keistimewaan provinsi daerah istimewa Aceh dan UU Republik Indonesia No 18 tahun 2001 tentang otonomi Khusus bagi provinsi Nanggroe Aceh Darussalam serta PERDA No 5 tahun 2000 tentang pelaksanaan Syari'at Islam maka terbentuklah sebuah lembaga WH yang dikuatkan dengan Surat Keputusan (SK) Gubernur Nanggroe Aceh Darussalam No 01 tahun 2004 tentang organisasi dan tata kerja Wilayatul Hisbah yang keberadaannya diharapkan untuk mengawasi pelaksanaan Syari'at Islam di Nanggroe Aceh Darussalam. Di samping itu untuk memperkuat pengawasannya di lapangan dibentuk pula muhtasib-muhtasib gampong yang terdiri dari tuha peut gampong dan tokoh-tokoh muda sebagai Wilayatul Qura yang bekerja secara suka rela ditingkat gampong masing-masing, lembaga ini diharapkan bisa bekerja mengawasi pelaksanaan Syari'at Islam di tingkat yang paling rendah dan satu hubungan yang bersifat koordinatif, konsultatif dan komunikatif dengan Wilayatul Hisbah yang bertugas di kecamatan dan Kabupaten.

Imam Mawardi dalam al-ahkam al-sulthaniyyah mengatakan; WH mempunyai tugas melaksanakan amar ma'ruf jika tampak nyata orang melalaikannya dan melakukan nahi mungkar jika tampak nyata orang mengerjakannya. WH mempunyai tugas yang sangat banyak dan luas, tak heran kalau Ibnu Khaldun menyetarakan fungsi wilayatul hisbah dengan fungsi Khilafah (pemerintahan). Semua yang diperintahkan dan dilarang oleh syara' adalah tugas muhtasib (petugas WH) untuk mengawasi terlaksana atau tidak di dalam 
masyarakat. Ia memasuki hampir seluruh sendi kehidupan masyarakat. Kewajibannya tidak terbatas dalam hal perintah memakai jilbab, perintah melaksanakan orang yang lalai shalat jumat, melarang berbagai maksiat dan kemungkaran, tetapi juga dalam bidang ekonomi, seperti mengawasi praktik jual beli dari riba, gharar, serta kecurangan, mengawasi standar timbangan dan ukuran yang biasa digunakan, memastikan tidak ada penimbunan barang yang merugikan masyarakat, mengawasi makanan halal, juga aspek sosial-budaya, seperti melarang kegiatan hiburan yang bertentangan dengan Islam, memberantas judi buntut, minuman keras, praktik asusila.

WH memasuki lorong-lorong kecil di kampung-kampung, setiap hari kerjanya adalah amar makruf nahi mungkar, tidak ada perkara syariat yang luput dari perhatiannya. WH adalah lembaga yang setiap hari berkampanye menumbuhkan kesadaran syariat Islam dan mengawasi pelaksanaannya dalam masyarakat. Sebab itu, muhtasib yang baik adalah yang lebih sering berada di jalanan, di pasar, di kampung-kampung memantau pelaksanaan syariat oleh masyarakat, daripada hanya sekedar berada di kantor.

Namun demikian WH hanya bertugas mengawasi hal-hal yang tampak dan sudah ma'ruf di kalangan masyarakat, yaitu perkara-perkara umum yang tidak ada perselisihan ulama tentang kewajiban melaksanakannya ataupun meninggalkannya, atau sering juga disebut perkara-perkara yang sudah menjadi 'uruf (adat) dalam keseharian masyarakat. Adapun perkara-perkara detail yang masih berupa was-was, dugaan, syak wasangka, dan memerlukan investigasi secara mendalam, pembuktian, kesaksian dan sumpah adalah bukan wewenang WH, tetapi menjadi wewenang lembaga lainnya yaitu wilayatul qadha' atau wilayatul mazalim. Untuk Aceh, WH juga bertugas mengawasi qanun-qanun yang berkaitan dengan syariat Islam yang telah ditetapkan.

Sebagaimana di kutip dari Dr, Jaribah dalam Fikih Ekonomi Umar Bin Khattab bahwa Hisbah merupakan cara pengawasan terpenting yang dikenal Islam pada masa permulaan Islam yang menyempurnakan pengawasan pribadi yang mempunyai kelemahan,untuk itu datanglah fungsi pengawas yang juga mengawasi tentang moral dan ekonomi. Lembaga ini memerintahkan kebaikan dan mencegah kemunkaran. Semua yang diperintahkan dan dilarang oleh syara' adalah tugas muhtasib (petugas Hisbah) untuk mengawasi terlaksana atau tidak di dalam masyarakat. Ia memasuki hampir seluruh sendi kehidupan masyarakat. Kewajibannya tidak terbatas dalam hal perintah memakai jilbab, perintah melaksanakan orang yang lalai shalat jum'at, melarang berbuat maksiat dan kemungkaran, tetapi juga dalam bidang ekonomi, seperti mengawasi praktik jual beli dari riba, gharar, serta kecurangan, mengawasi standar timbangan dan ukuran yang biasa digunakan, memastikan tidak ada penimbunan barang yang merugikan masyarakat, mengawasi makanan halal, juga aspek social budaya, melarang kegiatan hiburan yang bertentangan dengan Islam, memberantas judi, minuman keras. 
Menurut Al-Mawardi kewenangan lembaga hisbah ini tertuju kepada tiga hal yaitu: pertama, dakwaan yang terkait dengan kecurangan dan pengurangan takaran atau timbangan. Kedua, dakwaan yang terkait dengan penipuan dalam komoditi dan harga seperti pengurangan takaran dan timbangan pasar, menjual bahan makanan yang sudah kadarluarsa. Ketiga, dakwaan yang terkait dengan penundaan pembayaran hutang padahal pihak yang berhutang mampu membayarnya (Al-Mawardi t. tp:1973).

Wilayatul Hisbah adalah sebuah badan atau lembaga yang diperkenalkan kembali kepada masyarakat Aceh. Lembaga ini sudah sekian lama tidak dikenal oleh masyarakat seiring perkembangan zaman ke arah medernisasi. Sejarawan menyebutkan bahwa Wilayatul Hisbah merupakan lembaga yang popular di masamasa kejayaan agama Islam, sehingga istilah WH (kontek kekinian) terdapat dalam kitab-kitab fiqh terutama as-Siyasatusy Syar'iyyah, al-Ahkamus Sulthaniyyah atau an-Nuzhumul Islamiyah.

Dalam kitab As-Siyasatusy Syar'iyyah diuraikan tiga otoritas penegakan Hukum yaitu: pertama, Wilayatul Qadha yaitu lembaga atau badan yang berwenang untuk menyelesaikan sengketa sesama rakyat atau badan arbitrase (perdamaian). Kedua, Wilayatul Mazhalim yaitu lembaga atau badan yang berwenang menyelesaikan sengketa ketataniagaan negara serta sengketa antara pejabat dengan rakyat atau antara bangsawan dengan rakyat jelata (dalam istilah yudikatif sekarang disebut PTUN). Ketiga, Wilayatul Hisbah yaitu badan pemberi ingat dan badan pengawas. Atau yang berwenang mengingat anggota masyarakat tentang aturan-aturan yang harus di ikuti, cara menggunakan dan mentaati peraturan serta tindakan yang harus dihindari karena pertentangan dengan peraturan.

\section{Tugas Muhtasib}

Hisbah adalah sebuah institusi yang menjaga amar makruf dan menjauhi kemungkaran. Hisbah dalam cakupan yang luas, mengatur segala jenis hal dalam kehidupan kemasyarakatan. Termasuk ekonomi di dalamnya. Ketika Hisbah berdiri tegak dengan perangkat-perangkatnya, maka Ekonomi dapat berjalan dengan lancar dan sesuai dengan syariatNya. Subyek pelaku, dalam hal ini pejabat yang bertanggung jawab atas lembaga hisbah ini disebut muhtasib. Seorang muhtasib adalah orang yang diangkat oleh penguasa atau wakilnya untuk memonitor urusan rakyat, melihat kondisi mereka dan melindung kemaslahatannya (Chapra 2001: 64).

Tugas menjadi muhtasib adalah tugas yang berat. Tugas dimana segala sesuatu harus dijalankan dengan komprehensif. Muhtasib haruslah orang yang paham dalam kehidupan sosial terutama perdagangan atau perekonomian. Tugas seorang muhtasib dapat dibedakan sebagai berikut: pertama, berhubungan dengan hak-hak Allah. Mencegah tindak kemungkaran dalam muamalah, seperti riba, jual beli yang batil, penipuan dalam jual beli, kecurangan dalam harga, timbangan serta takaran. Kedua, berhubungan dengan hak-hak manusia. 
Mencegah tindakan menunda-nunda dalam menunaikan hak dan utang. Ketiga, berhubungan dengan layanan public, yaitu; menekankan pemilik hewan ternak untuk memberikan makan, dan tidak memanfaatkannya untuk pekerjaan yang tidak kuat, mengawasi transaksi pasar, jalan-jalan umum dan penarikan pajak, dan memuliakan produsen sehingga produknya bisa bersaing (Abu Sinn 2006: 199).

Diantara tujuan muhtasib (pengawas) adalah berusaha mewujudkan keamanan dan ketentraman serta memberantas segala tanda-tanda kerusakan keduanya. Derajat pengukuran hisbah; tindakan muhtasib menurut Imam Abu Hamid Al Ghazali yang harus dilakukan dengan benar dan penuh kesungguhan, yaitu: pertama, mencari tahu tentang kemungkaran tanpa harus memata-matai atau memaksa orang untuk memberi informasi.

Kedua, menasihati orang yang berbuat kedzaliman tersebut sebelum memberi hukuman. Ketiga, melarang dan menasihati dengan kata-kata. Keemapat, menggiatkan untuk takut yang sebenarnya pada Allah SWT. Kelima, mengingatkan dengan keras ketika kata-kata lembut sudah tidak mempan. Keenam, usahakan untuk membuat kemungkaran di jauhi secara fisik. Ketujuh, mewaspadai hal-hal yang mungkin akan buruk di masa yang bentar lagi datang, apalagi jika si pembuat kemungkaran belum sadar. Kedelapan, menjatuhi hukuman fisik tanpa menggunakan senjata untuk menghindari kerusakan atau darah tertumpah. Kesembilan, untuk memaksa regulasi, bisa lewat bantuan polisi juga untuk menuntut si pelaku kemungkaran dalam sistem konvensional ketika perangkat-perangkat sudah tegak dalam penerapan hisbah, maka hisbah akan sangat berperan dalam hal ekonomi (al-Haritsi 2006: 595).

Setelah kehadiran Undang-Undang Pemerintahan Aceh Nomor 11 Tahun 2006 kedudukan WH menjadi lebih jelas. Kalau sebelumnya keberadaan WH hanya berdasarkan Qanun Aceh, maka dalam undang-undang ini WH dianggap sebagai bagian dari SATPOL PP dan diberi nama Polisi Wilayatul Hisbah. Pengaturan tentang kewenangan, tugas, dan jenjang kepangkatan mengikuti peraturan perundang-undangan yang berlaku secara nasional. Secara nasional, tugas penegakan peraturan daerah dibebankan kepada SATPOL PP sesuai dengan jenjangnya masing-masing. Artinya Qanun Provinsi ditegakkan oleh Satpol PP Provinsi sedang Qanun kabupaten/kota ditegakkan oleh Satpol PP kabupaten/kota. Sedang tugas penyidikan atas pelanggaran PERDA menjadi tugas/kewenangan PPNS sesuai dengan jenjangnya masing-masing. Dengan demikian Polisi WH hanya berwenang melakukan sosialisasi, pengawasan dan pembinaan qanun syari'at Islam dan tidak berwenang melakukan penyidikan.

Menurut Undang-Undang Pemerintahan Aceh Nomor 11 Tahun 2006, otonomi khusus yang diberikan kepada Aceh, termasuk pelaksanaan Syari'at Islam (yang akan menjadi hukum Aceh) adalah kewenangan Provinsi dan dilaksanakan melalui Qanun Provinsi (Aceh). Qanun kabupate/kota tidak berwenang mengatur pelaksanaan Syari'at Islam (otonomi khusus) kecuali atas perintah Qanun Provinsi. Sedang tugas dan kewenangan penyidikan atas 
pelanggaran Qanun Provinsi menurut Undang-Undang Pemerintahan Aceh Nomor 11 Tahun 2006 dibebankan kepada PPNS Provinsi dan Penyidik Polisi, bukan hanya kepada PPNS. Dengan demikian Polisi WH baru berwenang melakukan penyidikan kalau telah memenuhi syarat dan sudah diangkat sebagai PPNS, sesuai dengan peraturan yang berlaku secara nasional.

\section{Kesimpulan}

Dari uraian di atas dapat di ambil kesimpulan betapa pentingnya peranan wilayatul hisbah dalam suatu pemerintahan, khususnya dalam hal pengawasan pasar. Peran WH sangat dibutuhkan sekali untuk membantu mewujudkan masyarakat yang memiliki standar moral yang tinggi, keunggulan akhlak dan menaati perkara-perkara yang sudah diwajibkan ataupun dilarang oleh syariat. Alangkah baiknya pembentukan WH dapat dijadikan salah satu agenda penting bagi pemerintah Indonesia di masa yang akan datang, bukan hanya saja di aceh, penerapan ini bisa dilaksanakan di keseluruhan bagian negeri ini, agar dengan kehadiran instutusi ini dapat menentramkan kehidupan perekonomian masyarakat. maka dari itu pemerintah dapat menyiapkan semua perangkat dan sumber daya manusia uang mempunyai kualitas untuk menjadi muhtasib sehingga proses penerapan WH dapat terwujud.

Untuk Aceh, hirarki struktural WH berada di bawah Dinas Syariat Islam. Tugas utamanya adalah mengawasi pelaksanaan syariat Islam oleh masyarakat. Posisinya sebagai "jantung" dalam Dinas Syariat Islam sangat menentukan keberhasilan atau kegagalan Dinas ini menegakkan syariat. Untuk itu landasan hukum tersendiri yang jelas yang mengatur tugas dan wewenang institusi hisbah sangat diperlukan di samping tekad yang kuat dari petugas WH menegakkan syariat.Pembentukan institusi ini adalah sangat positif dan perlu dukungan padu semua pihak. Kunci kesuksesan WH nantinya akan terlihat ketika masyarakat dengan kesadaran keagamaan yang tinggi terwujud. Yaitu masyarakat dengan standar moral yang tinggi, keunggulan akhlak, dan menaati perkara-perkara yang sudah diwajibkan atau dilarang oleh syari'at. Tetapi, ketika maksiat kembali merajalela, perbuatan amoral merebak, masyarakat berlaku curang, menipu, dan memakan riba dalam berdagang, maka jelas, WH tidak berperan dengan sempurna. WH, juga aparat pemerintah lainnya telah gagal menegakkan syari'at. 


\section{Daftar Pustaka}

Abu Sinn, Ahmad Ibrahim. 2006 . Manajemen Syariah: Sebuah Kajian Historis Dan Kontemporer. Jakarta:Raja Grafindo Persada.

Al-Mawardi. 1973. Al-Ahkam as-Sulthaniyah wa al-Wilayah ad-Diniyyah. Kairo, tp. al-Haritsi, Jaribah bin Ahmad. 2006. Fikih Ekonomi Umar bin al-Khattab, terj. Asmuni Zamakhsyari. Solihan. Jakarta: Khalifa.

Chapra. M. Umer. 2001. Masa Depan Imu Ekonomi, Sebuah Tinjauan Islam. Jakarta: Gema Insani.

Ahmad, Mustaq. 2001. Business Ethics In Islam, terj. Indonesia: Etika Bisnis Dalam Islam oleh Samson Rahman, Jakarta: Pustaka al-Kautsar.

Adiwarman A., Karim. 2007. Ekonomi Mikro Islami; edisi ketiga. Jakarta: Raja Grafindo Persada.

----------. 2010. Sejarah Pemikiran Ekonomi Islam. Jakarta: PT. Raja Grafindo Persada.

Harahap, Sofyan S. 2011. Etika Bisnis dalam Perspektif Islam. Jakarta : Salemba Empat.

Hafas Furqoni. 2007. http://id.acehinstitute.org

Ibrahim Abu Sinn, Ahmad. 2006. Manajemen Syariah:sebuah kajian historis dan kontemporer. Jakarta: Raja Grafindo Persada.

Karim, Adiwarman A. 2001. Ekonomi Islam, suatu kajian kontemporer. Jakarta: Gema Insani Press.

Muhammad. 2004. Etika Bisnis Islami. Yogyakarta: UPP-AMP YKPN. 